Phil Teece, who spoke at last year's conference, has just completed his report on wages and salaries in the library sector. The report is to be released this week and anyone interested in reading it should contact ALIA.

In December the Association received news that Mark Sutherland was resigning in June and we note the appointment of Jocelyn Morris as his replacement. Jocelyn's position at the Camden Theological Library is currently being advertised.

Finally it is left for me to record with great sadness the death of Pam Carswell in December. Pam's work for the Association was recognised last year when she was awarded Honorary Life Membership. She will be greatly missed by the Association.

Kim Robinson

$2^{\text {nd }}$ July 1999

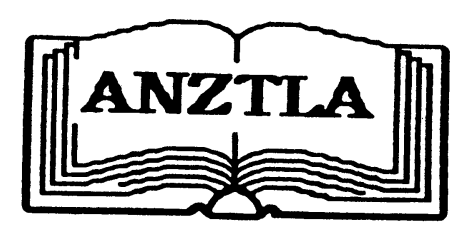

\title{
The Vice-President's Report on the Adelaide Conference
}

\begin{abstract}
Philip Harvey
This report, in slightly altered form, was delivered by the ANZTLA Vice President at the conclusion of the ANZTLA Conference at Luther Seminary, Adelaide, on Sunday afternoon the $3^{\text {rd }}$ of July 1999.

On Thursday night we heard Marion Maddox. She reminded us that in our culture we are used to putting the world on the page as a way of organising reality. However, though the words are the same the meaning can change from age to age. She used the Hindmarsh business in South Australia as an example of how oral tradition values and structures knowledge differently. Entranced with our own version of truth we can fail to recognize other ways of knowledge that are also valuable and valid. She confessed to going through her own crosscultural shift recently, from the university environment to the public service. Spirit was the source of all freedom, now it's a computer that checks her work time. Marion reminded us that the digital revolution is just another formulation of the written culture all around us.
\end{abstract}

On Friday morning cataloguers heard a full summary of the AACR2 Conference in Toronto (1997) from Philip Harvey. The whole can of worms was put on the table: first principles, seriality, access points, the very need for MARC tags, bibliographic relationships, and minimum displays. The online environment has come to determine future direction of the Rules. Cataloguers are caught up with the vexatious, variable, verified subfield $\$ \mathrm{v}$, the form subdivision. Why was this ever thought of?, asks the international community, but cataloguers must now learn to distinguish a $\$ \mathrm{v}$ from an $\$ \mathrm{x}$ in every case. A useful report of cataloguing practices across ANZTLA took up the second session, followed by the worst subject headings of the year, with first prize going to 'Schwenkfelders - Czech Republic - Silesia - History.' 
Jan Gaebler spoke on marketing our libraries and about their 'value', by which she meant something other than just their monetary value. How do we describe the 'value' of our libraries? What 'value' do we contribute to our organisation? What do you think your boss would say about your 'value'? If these don't correlate in some way there is a problem. She assured us never to feel threatened by a review, but to see it as a marketing and promotional opportunity. One saying was: Promote the product, not the place.

Information literacy was an interactive workshop facilitated by Irene Doskatsch. What is information literacy? It is the ability to access, locate, evaluate and use all forms of media. Many librarians believe information literacy is informational skills, but it is a much broader concept and builds on information skills relating to book, journals, videos, films, CD Roms, and computers with all their ramifications.

A professional development session was run by Janine Tan and Jocelyn Morris. According to reports, a domestic started the meeting and then they pretended it was a role play and Don wasn't seen again. If there is an employer and an employee then a mentor can have a mentee, prompting the remark that it's moments like these you need a mentee. Barbara Frame talked about job exchange. Is it a good thing? You can get mismatches and a lot of effort can be expended. Lesley Utting talked about programs giving credit for professional development. Auditing frameworks are coming out accredited by the respective library associations. Both ALIA and LIANZA are setting in place formal programs for auditing professional development. They re-emphasized that we need to be connected to the wider library world through our Associations.

Jenny Tonkin from the South Australian State Library spoke on preservation. Conservation hazards can go to extremes and Jenny related her experiences when working at Ernabella of dogs peeing on keyboards, mice biting through cables, and (presumably) feral cats playing with mouses. Kit Smith reported on conservation measures for music collections at St Patrick's College and St Mary's Cathedral in Sydney. Everyone was greatly impressed with a draughtsman's implement designed by her husband for scraping white numbers off book leather. Judith Bright talked about New Zealand Anglican and Methodist collections and the question of Preservation versus Access. The classification at Auckland was re-worked to reflect provenance rather than subject. Two maxims from this session were: Don't do anything until you call in an expert; and, Don't be prepared to throw out until the bottom of the last tea chest.

That afternoon a large contingent visited Artlab, the conservation division of the South Australian Museum. The mummy was still at the morgue. The William Morris rug was on the table. The prayer-book had been dismembered. Just another day at Artlab.

On Friday night creative hermeneutics linked Qumran cave 4 ('the sexy cave') with theological librarianship. We were told that we are the mediators of religious meaning, connecting people to their deepest search. Like Marion Maddox, Michael Trainor re-emphasized the centrality of the written word, writing, a notable assertion in this age of cyberspace. He used ancient visual stimuli to illustrate the religious in everyday life via the use of a suggestive red light pen: nurture (the Anatolian cybele); the sacredness of the ordinary (Upper Nile); writing as an act of the gods (Thoth the Egyptian ibis god); libraries at religious and healing centres (Delphi and Pergamon); writing as the preservation of religious identity (Qumran at the Dead 
Sea); and libraries at the religious and commercial heart of society (Ephesus). He drew to our attention the four statues outside the Celsum Library at Ephesus: Thought, Knowledge, Goodness, Wisdom.

Next morning Kim Robinson spoke about everything, what is available in reference resources if we had a limitless budget. Tony McCumstie spoke on the budget, how much we realistically hope to have of everything. Because reference is so expensive it needs to be treated as a special part of the budget. The price of reference works is, on average, twice that of a normal book. Faculty need to be made aware of how expensive they can be. Special funding becomes a means to purchase costly items. Judith Bright spoke about actual choice, what we do once we realize we can't have everything. Is there something we can call an essential reference text? Decisions are determined by denomination, place, type of teaching institution. The slogan is: Know your community, know your collection. What we want is built-in reliability.

How wise is the Web?, Beth Prior asked. One reply would be, not as wise as the person who cut the statue of Sophia outside the library at Ephesus. After all, the Web is just electricity. Natalie Schwarz admitted that the internet can be like finding the silver chalice in a mountain of polystyrene coffee cups. We have lots of information 24 hours a day. The internet offers many things that a reference collection will not. It can be anarchic, junky, biassed, changeable. It is poorly indexed and needs evaluation at every turn. Presentation and not text can be dominant. Important strategies on the Web : define your search task, list synonyms and keywords, determine the type of information, select the appropriate tool, critically examine the results, document your results, e.g. bookmark the site. The rate of search engine access decreases year by year as the Web expands exponentially, a reason for further improving our search strategies.

This year we heard site insights from Irene Mills at Wagga, Barbara Hattrell from Tasmania. Kolotai Mau from Tonga, and Jeanette Little from Fiji if not the rest of the Pacific.

After a Kinetica update from Tom Ruthven, where the silences were as significant as the questions asked, we all hopped on the bus and went to McLaren Vale for the afternoon, from whence came some of the inspiration for this paper.

The conference was successful both as a source of information for theological librarians and as a social means for networking. Everyone in Adelaide is to be congratulated, though special thanks must go to the members of the Conference Committee, Val Canty, Blan McDonagh, Mark Sutherland, and in particular Beth Prior.

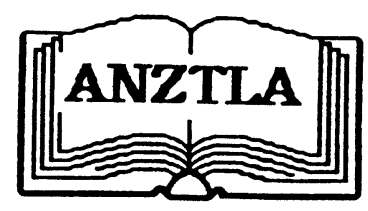

